\title{
Relationship Between Fragmented QRS Complex and Maternal Demographic Features and Echocardiographic Parameters in Pregnancy
}

\author{
Gebelikte Fragmente QRS Kompleksi ile Maternal Demografik Özellikler ve \\ Ekokardiyografik Parametreler Arasındaki İlişki \\ Veciha Özlem Bozkaya \\ Keçiören Training and Research Hospital, Department of Cardiology, Ankara \\ Yazıșma Adresi / Correspondence: \\ Veciha Özlem Bozkaya \\ Department Of Cardiology, Keçiören Training and Research Hospital, Keçiören, Ankara \\ T: +903123569000 E-mail : vobozkaya@gmail.com \\ Geliş Tarihi / Received : 11.11.2019 Kabul Tarihi / Accepted : 10.01.2020 \\ Orcid : \\ Veciha Özlem Bozkaya https://orcid.org/: 0000-0002-2876-9239 \\ (Sakarya Tip Dergisi / Sakarya Med J 2020, 10(1):17-22) DOI: 10.31832/smj.645580
}

\footnotetext{
Abstract

Objective The aim of this study was to investigate the relationship between the presence of fragmented QRS (f-QRS) complex on electrocardiography (ECG) and maternal demographic characteristics and left ventricular systolic and diastolic dysfunction on echocardiography.

Materials 473 pregnant women enrolled in this study and divided into two groups. (f-QRS positive group $\mathrm{n}=77$, $\mathrm{f}-\mathrm{QRS}$ negative group $\mathrm{n}=396$ ). Maternal demographic features and and Methods echocardiographic parameters of all participants were recorded and compared between two groups.

Results The mean age of the study population was $27.70 \pm 5.62$ and mean gestational week was $7.37 \pm 1.55$. Parity in $\mathrm{f}-\mathrm{QRS}$ positive group was higher than in control group ( $\mathrm{p}=0.01)$. There was a statistically significant trend between fragmentation frequency and parity number $(\mathrm{p}=0.002)$. There were no significant differences between two groups in terms of age, gestational week, heart rate, body mass index. Left ventricle end-systolic and diastolic diameters and left ventricular ejection fraction were similar between the two groups

Conclusion The presence of $\mathrm{f}-\mathrm{QRS}$ was correlated with increase in number of parity and we suggest that multiparity may be a risk factor for cardiac events during pregnancy. Pregnant women with $\mathrm{f}$-QRS on their rest ECG need extra attention in terms of cardiovascular disease. By demonstrating clinical significance of $\mathrm{f}-\mathrm{QRS}$, this simple tool might be used to determine women who could be at risk for developing cardiac dysfunction in pregnancy.

Keywords QRS fragmentation; pregnancy; echocardiography

Öz

Amaç Bu çalșmanın amacı, elektrokardiyografide (EKG) fragmente QRS (f-QRS) kompleksi varlğ̆ ile maternal demografik özellikler ve ekokardiyografide sol ventrikül sistolik ve diyastolik disfonksiyonları arasında ilişkiyi araștırmaktır

Gereçve Calısmaya 473 gebe dahil edildi ve iki gruba ayrlldı $(f$-QRS pozitif grup $n=77, f$-QRS negative grup $n=396$ ). Tüm katıllmcıların maternal demografik özellikleri ve ekokardiyografik paraYöntemler metreleri kaydedildi ve iki grup arasinda karșılaștırild.

Bulgular Çalş̧ma popülasyonunun yaş ortalaması $27.70 \pm 5.62$, gebelik haftası ortalama $7.37 \pm 1.55$ idi. $f$-QRS pozitif gruptaki parite kontrol grubundan daha yüksekti $(p=0.01)$. Fragmentasyon sıklı̆ı ve parite sayısı arasında istatistiksel olarak anlamlı bir eğilim vardı. ( $p=0.002$ ). İki grup arasında yas, gebelik haftası, kalp hizl, vücut kitle indeksi açısından anlamlı fark yoktu. Sol ventrikül end sistolik ve diyastolik çaplar ve sol ventrikül ejeksiyon fraksiyonu iki grup arasinda benzerdi

Sonuç F-QRS varly̆ğ parite sayısındaki artısla korele idi ve multiparitenin gebelikte kardiyak olaylar için bir risk faktörü olabileceğini düşünüyoruz. İstirahatinde f-QRS olan gebelerin EKG’si kardiyovasküler hastalıklar açısından ekstra dikkat gerektirmektedir. f-QRS’nin klinik önemini göstererek, bu basit araç gebelikte kardiyak disfonksiyon gelișimi riski tașlyan kadınları belirlemek için kullanılabilir. 


\section{INTRODUCTION}

Fragmented QRS complex (f-QRS) on electrocardiogram (ECG) was first detected in patients with coronary artery disease. The $\mathrm{f}-\mathrm{QRS}$ is an easily evaluated non-invasive electrocardiographic parameter and has been suggested as a marker of myocardial fibrosis and scar tissues associated with arrhythmic events and worse prognosis in patients with hearts diseases. ${ }^{1}$ Heterogeneous activity caused by myocardial fibrosis and scar tissue in the ventricles may be a possible cause of fragmentation in patients with heart disease. On the other hand, this ECG sign can be found in healthy persons too and underlying mechanisms and clinical implications of $\mathrm{f}-\mathrm{QRS}$ among healthy people remain unknown. Pregnancy is a physiological clinical condition with some changes in the cardiovascular system such as a $50 \%$ increase in plasma volume, a $17 \%$ increase in heart rate, and a $50 \%$ increase in cardiac output. ${ }^{2,3}$ The incidence and severity of arrhythmias increase during pregnancy. Although the exact mechanism is unclear, increased plasma volume, increased sympathetic activity and hormonal changes were suspected. ${ }^{4}$ Because of dyspnoea, palpitation and limitation in effort capacity are common complaints among pregnant women; diagnosis of cardiac diseases is disingenuous during pregnancy. Since cardiovascular disease (CVD) is the most common cause of death during pregnancy and findings can be masked with normal pregnancy complaints, early diagnosis of CVD may be difficult. ${ }^{5}$ Therefore, it is important to evaluate the findings predicting cardiac risk at the beginning of pregnancy and to reveal the relationship between these findings and maternal characteristics. For this purpose, we evaluated $\mathrm{f}-\mathrm{QRS}$ as a non-invasive, easily and cheap method and a predictive marker for arrhytmogenesis and cardiac events. It would be interesting that the marker, which can be easily evaluated with surface ECG, can identify pregnant women with high cardiac risk at the beginning of pregnancy. In previous studies, some of ECG parameters have been evaluated. ${ }^{6}$ To the our knowledge this is the first study investigates the relationship $\mathrm{f}-\mathrm{QRS}$ and maternal demographic and echocardiographic parameters.

\section{Material And Methods}

This cross-sectional study was conducted between December 2018 and March 2019 in a tertiary delivery center, Ankara, Turkey. 473 pregnant women who admitted cardiology outpatient clinic enrolled in this study and divided into two groups (f-QRS positive group $n=77, f-Q R S$ negative group $\mathrm{n}=396)$. A written and verbal consent was obtained from all patients. The study protocol was approved with ethical committee number 41/2019. All patients' medical history and demographic features (age, gravida, parity, weight, height, body mass index, systolic and diastolic blood pressure) were recorded. Patients with a history of chronic systemic disease, prior cardiovascular disease (CVD), multiple pregnancies and cases with high-risk pregnancy were excluded from the study. A 12-lead ECG (AT-102, Schiller AG, Switzerland) was recorded for each pregnant at rest while in the supine position. Additionally, patients who observed any arrhythmia, pre-excitation syndrome, complete/incomplete right or left bundle branch block, left posterior or anterior fascicular block, intraventricular conduction delay (QRS duration $>120 \mathrm{~ms}$ ) or significant repolarization abnormalities and long- or short-QT syndrome on the routine 12-lead ECG were excluded from the study. Fragmentation of QRS is defined as presence of an additional $R$ wave ( $R$ ') or notching in the nadir of the $S$ wave, or the presence of $>1 \mathrm{R}^{\prime}$ in at least two contiguous leads, corresponding to a major coronary artery territory on the resting 12-lead ECG. ${ }^{7}$ Recordings were acquired at a paper speed of $25 \mathrm{~mm} / \mathrm{s}$, with $1 \mathrm{mV} / \mathrm{cm}$ standardization. Transthorasic Echocardiography (TTE) (Vivid S5 System, GE Health-care, USA) was performed and following data were recorded; left ventricle end-diastolic diameter (LVEDD), left ventricle end-systolic diameter (LVESD), left ventricular ejection fraction (LVEF\%), right atrium diameter (RAEDD), right ventricle end diastolic diameter (RVEDD), left atrium end diastolic diameter (LAEDD), mitral E wave velocity $(\mathrm{cm} / \mathrm{s})$, mitral A wave velocity $(\mathrm{cm} / \mathrm{s})$, tricuspid annular plane systolic excursion (TAPSE), isovolumic relaxation time (IVRT), isovolumic contraction time (IVCT), TAPSE. Left ventricular dimen- 
sions were determined using two-dimensional directed M-Mode echocardiography in the long axis of parasternal view. Systolic function was assessed by the left ventricular ejection fraction according to the Teicholz formula. Left ventricular diastolic function was evaluated by transmitral Doppler using the pulsed-Doppler technique with 2D guidance in the apical four-chamber view. All echocardiography recordings were analyzed using standard techniques. ${ }^{8}$

All analyses were conducted using SAS JMP v11 (SAS Institute Inc., Cary, NC, 1989-2019). Numeric variables were given as mean \pm standard deviation (SD). Normality of distributions was evaluated with Shapiro-Wilk W Test. Parameter comparison was performed with Student's t-test form normally distributed parameters and Mann-Whitney $\mathrm{U}$ test were used for non-normal distributions.

\section{Results}

The mean age of study population was $27.70 \pm 5.62$ and mean gestational week was $7.37 \pm 1.55$. The demographical features and echocardiographic findings of study population were listed in table 1 and table 2.

\begin{tabular}{|l|c|c|c|}
\hline \multicolumn{4}{|c|}{ Table1. The demographical features of study population } \\
\hline Characteristic & $\begin{array}{c}\text { f-QRS(-) } \\
(\mathbf{n}=\mathbf{3 9 6})\end{array}$ & $\begin{array}{c}\text { f-QRS(+) } \\
(\mathbf{n}=77)\end{array}$ & p Value \\
\hline Age, years & $27,54 \pm 5,61$ & $28,53 \pm 5,65$ & 0,18 \\
\hline Parity, $\mathrm{n}$ & $0,87 \pm 0,95$ & $1,25 \pm 1,14$ & 0,01 \\
\hline Weight, kg & $65,44 \pm 12,59$ & $68,25 \pm 13,18$ & 0,07 \\
\hline Height, cm & $161,04 \pm 6,60$ & $161,28 \pm 6,37$ & 0,86 \\
\hline BMI, kg/m2 & $25,24 \pm 4,71$ & $26,29 \pm 5,18$ & 0,14 \\
\hline Gestational week & $7,34 \pm 1,47$ & $7,56 \pm 1,92$ & 0,57 \\
\hline HR, bmp & $79,27 \pm 10,80$ & $77,62 \pm 11,39$ & 0,20 \\
\hline $\begin{array}{l}\text { Values are presented as mean } \pm \text { SD. }{ }^{*} \text { Mann-Whitney U test } \\
\text { Abbreviations: Body mass index (BMI), Heart rate (HR), QRS fragmenta- } \\
\text { tion negative (f-QRS (-)), QRS fragmentation positive (f-QRS (+)) }\end{array}$ \\
\hline
\end{tabular}

\begin{tabular}{|c|c|c|c|}
\hline \multicolumn{4}{|c|}{$\begin{array}{l}\text { Table2. The echocardiographic parameters in study popula- } \\
\text { tion }\end{array}$} \\
\hline Characteristic & $\begin{array}{c}\text { f-QRS(-) } \\
(\mathbf{n}=396)\end{array}$ & $\begin{array}{c}\text { f-QRS }(+) \\
(\mathbf{n}=77)\end{array}$ & p value \\
\hline LVEF, \% & $67,63 \pm 2,31$ & $67,99 \pm 2,31$ & 0,32 \\
\hline $\mathrm{E}, \mathrm{m} / \mathrm{s}$ & $0,99 \pm 0,14$ & $0,95 \pm 0,12$ & 0,03 \\
\hline $\mathrm{E}^{\prime}, \mathrm{cm} / \mathrm{s}$ & $13,34 \pm 2,06$ & $13,07 \pm 2,00$ & 0,35 \\
\hline $\mathrm{E} / \mathrm{E}^{\prime}$ & $7,56 \pm 1,55$ & $7,44 \pm 1,47$ & 0,55 \\
\hline $\mathrm{A}, \mathrm{m} / \mathrm{s}$ & $0,77 \pm 0,13$ & $0,73 \pm 0,12$ & 0,03 \\
\hline $\mathrm{A}^{\prime}, \mathrm{cm} / \mathrm{s}$ & $9,68 \pm 2,31$ & $10,29 \pm 2,61$ & 0,22 \\
\hline $\mathrm{DT}, \mathrm{msn}$ & $189,20 \pm 47,22$ & $208,38 \pm 49,69$ & $<0,01$ \\
\hline IVRZ, ms & $76,98 \pm 15,74$ & $80,38 \pm 11,13$ & 0,05 \\
\hline LVESD, $\mathrm{cm}$ & $2,83 \pm 0,32$ & $2,92 \pm 0,32$ & 0,11 \\
\hline LVEDD, $\mathrm{cm}$ & $4,33 \pm 0,29$ & $4,34 \pm 0,28$ & 0,65 \\
\hline RAEDD, $\mathrm{cm}$ & $2,95 \pm 0,33$ & $2,97 \pm 0,36$ & 0,92 \\
\hline RVEDD, $\mathrm{cm}$ & $2,12 \pm 0,22$ & $2,12 \pm 0,21$ & 0,91 \\
\hline LAEDD, $\mathrm{cm}$ & $2,87 \pm 0,34$ & $2,84 \pm 0,31$ & 0,48 \\
\hline TAPSE, $\mathrm{cm}$ & $2,21 \pm 0,27$ & $2,19 \pm 0,16$ & 0,53 \\
\hline \multicolumn{4}{|c|}{ 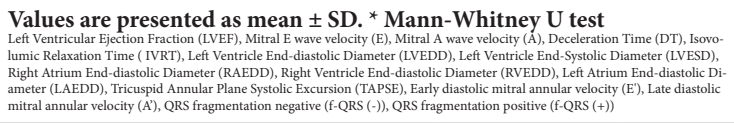 } \\
\hline
\end{tabular}

There were no significant differences between two groups in terms of age, gestational week, heart rate, Body mass index. Left ventricle end-systolic and diastolic diameters and LVEF were similar between the two groups. Parity number in $\mathrm{f}-\mathrm{QRS}$ positive group was higher than in control group $(\mathrm{p}=0.01)$. The prevalence of fragmentation increases with increasing number of parity (Figure 1).

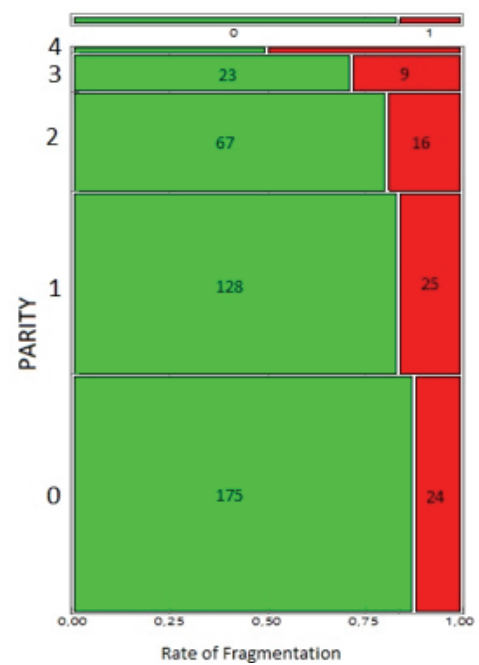

Figure 1. Mosaic Plot of the fragmentation rates by parities 
Values in table 3 shows that there is a statistically significant trend between fragmentation frequency and parity number $(\mathrm{p}=0.002)$.

\begin{tabular}{|c|c|c|c|}
\hline \multirow{2}{*}{ Parity } & \multicolumn{2}{|c|}{ N (\%) } & \multirow{2}{*}{ p value } \\
\hline & f-QRS (-) & f-QRS (+) & \\
\hline 0 & $175(87,94)$ & $24(12,06)$ & \multirow{6}{*}{$0.002^{\star}$} \\
\hline 1 & $128(83,66)$ & $25(16,34)$ & \\
\hline 2 & $67(80,72)$ & $16(19,28)$ & \\
\hline 3 & $23(71,88)$ & $9(28,13)$ & \\
\hline 4 & $3(50,00)$ & $3(50,00)$ & \\
\hline Total & $396(83.72)$ & $77(16.18)$ & \\
\hline \multicolumn{4}{|c|}{$\begin{array}{l}\text { * Cochran Armitage Trend Test } \\
\text { QRS fragmentation negative (f-QRS (-)), QRS fragmentation positive } \\
(\mathrm{f}-\mathrm{QRS}(+))\end{array}$} \\
\hline
\end{tabular}

\section{Discussion}

This study demonstrated that the prevalence of $f-Q R S$ among pregnant women was $16.18 \%$ and the presence of $\mathrm{f}-\mathrm{QRS}$ was correlated with the number of parity in pregnant women. When the two groups ( $\mathrm{f}-\mathrm{QRS}$ negative group and $\mathrm{f}-\mathrm{QRS}$ positive group) were compared, no statistically significant difference was observed in terms of clinical echocardiographic parameters.

During pregnancy, a number of changes in the cardiovascular system occur as follows: heart rate, cardiac output and intravascular volume are increased; blood pressure diminishes in the first trimester and returns to its normal level during the third trimester. ${ }^{9}$ Incidence of maternal cardiac arrhythmias increases during pregnancy. ${ }^{10}$ Although the exact mechanism is not clear; increased plasma volume, increased sympathetic activity and hormonal changes were suspected. ${ }^{3}$ Some changes may occur on ECG during pregnancy, such as deviation of the QRS axis, a small Q wave and an inverted $\mathrm{P}$ wave in lead III, an increased R/S ratio in leads $\mathrm{V} 2-\mathrm{V} 6$, changes in the ST segment and $\mathrm{T}$ wave. ${ }^{11}$ In the literature, some studies suggest that electrocardiographic parameters may be predictive for cardiovascular diseases and poor obstetric prognosis in pregnancy such as P Wave dispersion and QT dispersion. ${ }^{12}$ However, there is no information about $\mathrm{f}-\mathrm{QRS}$ in pregnant women. Fragmented QRS on ECG has been found a marker of myocardial scarring or fibrosis in various diseases. ${ }^{13}$ The $\mathrm{f}-\mathrm{QRS}$ is cheap and readily available electrocardiographic index of myocardial fibrosis. In the pregnancy, which is a physiological condition accompanied by cardiovascular changes, it may be useful to determine easily evaluated parameters in pregnancy in terms of the reaction of pregnant women with cardiac risk in the early period. Based on this hypothesis, we investigated $\mathrm{f}-\mathrm{QRS}$ in pregnant women and determined that the frequency of fragmentation on rest ECG of pregnant women was $16.18 \%(n=77 / 496)$. In a previous study, Ying $\mathrm{T}$ et all. found that the prevalence of $\mathrm{f}-\mathrm{QRS}$ in healthy adult was $5.1 \%{ }^{14}$ Since there are no studies examining the frequency of fragmentation in the pregnant population in the literature, we found higher prevalence than the general population, making the presence of fragmentation more interesting in this patient group. Additionally, we found higher number of parity in $\mathrm{f}$-QRS positive group than $\mathrm{f}-\mathrm{QRS}$ negative group and there was a statistically significant trend between fragmentation frequency and parity number. Previous epidemiological studies suggest that multiparity (multiple pregnancies) increases the risk of cardiovascular disease. ${ }^{15}$ The mechanisms underlying these findings remain to be elucidated. ${ }^{16}$ The mechanism of the association of parity and CVD is not well understood. Estrogen is considered as a protective factor against the developing of CVD. The secretion of estrogen is discontinued during normal pregnancy depending on the reset of ovarian function. More parity and pregnancy mean more exposure to estrogen reduction. ${ }^{17}$ Number of parity is also reported to be associated with carotid artery atherosclerosis in elderly women..$^{18,19}$

There is no data as to whether the presence of $\mathrm{f}-\mathrm{QRS}$ predicts pronounced LV systolic and diastolic dysfunction in pregnant women. In a previous study, the presence of f-QRS on ECG was associated with higher E/E' ratio and lower E' velocity, indicating pronounced diastolic dysfun- 
ction among patients with metabolic syndrome. ${ }^{20}$ Our study demonstrated that in $\mathrm{f}-\mathrm{QRS}$ positive group compared to $\mathrm{f}-\mathrm{QRS}$ negative group, showed a longer deceleration time. Future studies are needed to investigate the clinical significance of this relationship.

In conclusion, the presence of $\mathrm{f}-\mathrm{QRS}$ was associated with number of parity and we suggest that multiparity may be a risk factor for arrhythmia and other cardiovascular events. Pregnant women with $\mathrm{f}-\mathrm{QRS}$ on their rest ECG need extra attention in terms of cardiovascular disease. Future studies which investigate association between presence of $\mathrm{f}-\mathrm{QRS}$ and pregnancy outcomes and clinical significance of $\mathrm{f}-\mathrm{QRS}$ in pregnancy are needed. This simple tool might help to identify pregnant women who could be at risk for developing overt cardiac dysfunction.

\section{Conclusions}

The presence of $f-Q R S$ was correlated with increase in number of parity. Pregnant women with $f-Q R S$ on their rest ECG need extra attention in terms of cardiovascular disease. By demonstrating clinical significance of $f-Q R S$, this simple tool might be used to determine women who could be at risk for developing cardiac dysfunction in pregnancy.

\section{Limititations}

One of the limitations of our study is that we did not assess prospectively association between the presence of $f-Q R S$ and pregnancy outcomes. Secondly, since we used echocardiography as imaging method we did not show cardiac fibrosis with other imaging modalities.

The author received no specific funding for this work and declares no competing interests. 
Sakarya Med J 2020;10(1):17-22

BOZKAYA, Fragmented QRS in Pregnancy

\section{References}

1. Das MK, Saha C, El Masry H, Peng J, Dandamudi G, Mahenthiran J, et al. Fragmented QRS on a 12-lead ECG: a predictor of mortality and cardiac events in patients with coronary artery disease. Heart rhythm 2007;4(11):1385-92. doi: 10.1016/j.hrthm.2007.06.024. PubMed PMID: 17954396.

2. Franklin WJ, Benton MK, Parekh DR. Cardiac disease in pregnancy. Texas Heart Institute journal 2011;38(2):151-3. PubMed PMID: 21494524; PubMed Central PMCID: PMC3066821.

3. O'Kelly AC, Sharma G, Vaught AJ, Zakaria S. The Use of Echocardiography and Advanced Cardiac Ultrasonography During Pregnancy. Curr Treat Options Cardiovasc Med. 2019 Nov 21;21(11):71. doi: 10.1007/s11936-019-0785-5. PMID: 31754837

4. Adamson DL, Nelson-Piercy C. Managing palpitations and arrhythmias during pregnancy. Heart 2007;93(12):1630-6. doi: 10.1136/hrt.2006.098822. PubMed PMID: 18003696; PubMed Central PMCID: PMC2095764.

5. Bouvier-Colle MH, Mohangoo AD, Gissler M, Novak-Antolic Z, Vutuc C, Szamotulska K, et al. What about the mothers? An analysis of maternal mortality and morbidity in perinatal health surveillance systems in Europe. BJOG : an international journal of obstetrics and gynaecology 2012;119(7):880-9; discussion 90. doi: 10.1111/j.1471-0528.2012.03330.x. PubMed PMID: 22571748; PubMed Central PMCID: PMC3472023.

6. Akdemir N1, Akarsu S, Türe S, Ozlem Akcinar V, et al. Evaluation of the relationship between heart type fatty acid binding protein levels and the risk of maternal cardiac ischemia in low risk obstetric population during delivery.Med Glas (Zenica). 2012 Aug;9(2):256-61. PMID: 22926360

7. Pietrasik G, Zareba W. QRS fragmentation: diagnostic and prognostic significance. Cardiology journal 2012;19(2):114-21. PubMed PMID: 22461043.

8. Lang RM, Bierig M, Devereux RB, Flachskampf FA, Foster E, Pellikka PA, et al. Recommendations for chamber quantification: a report from the American Society of Echocardiography's Guidelines and Standards Committee and the Chamber Quantification Writing Group, developed in conjunction with the European Association of Echocardiography, a branch of the European Society of Cardiology. Journal of the American Society of Echocardiography: official publication of the American Society of Echocardiography 2005;18(12):1440-63. doi: 10.1016/j.echo.2005.10.005. PubMed PMID: 16376782.

9. Soma-Pillay P, Nelson-Piercy C, Tolppanen H, Mebazaa A. Physiological changes in pregnancy. Cardiovascular journal of Africa 2016;27(2):89-94. doi: 10.5830/CVJA-2016-021. PubMed PMID: 27213856; PubMed Central PMCID: PMC4928162.

10. Cordina R, McGuire MA. Maternal cardiac arrhythmias during pregnancy and lactation. Obstetric medicine 2010;3(1):8-16. doi: 10.1258/om.2009.090021. PubMed PMID: 27582834; PubMed Central PMCID: PMC4989762.
11. Wenger NK, Hurst JW, Strozier VN. Electrocardiographic Changes in Pregnancy. The American journal of cardiology 1964;13:774-8. doi: 10.1016/0002-9149(64)90426-6. PubMed PMID: 14175532 .

12. Ozmen N, Cebeci BS, Yiginer O, Muhcu M, Kardesoglu E, Dincturk M. P-wave dispersion is increased in pregnancy due to shortening of minimum duration of $P$ : does this have clinical significance? The Journal of international medical research 2006;34(5):468-74. doi: 10.1177/147323000603400503. PubMed PMID: 17133775.

13. Das MK, Khan B, Jacob S, Kumar A, Mahenthiran J. Significance of a fragmented $Q R S$ complex versus a $Q$ wave in patients with coronary artery disease. Circulation 2006;113(21):2495-501. doi: 10.1161/CIRCULATIONAHA.105.595892. PubMed PMID: 16717150.

14. Seong CS, Gwag HB, Hwang JK, Park SJ, Park KM, Kim JS, et al. Clinical significance of fragmented QRS complexes or J waves in patients with idiopathic ventricular arrhythmias. PloS one 2018;13(4):e0194363. doi: 10.1371/journal.pone.0194363. PubMed PMID: 29694354; PubMed Central PMCID: PMC5919047.

15. Shen L, Wu J, Xu G, Song L, Yang S, Yuan J, et al. Parity and Risk of Coronary Heart Disease in Middle-aged and Older Chinese Women. Scientific reports 2015;5:16834. doi: 10.1038/ srep16834. PubMed PMID: 26607032; PubMed Central PMCID: PMC4660373.

16. Dhawan V, Brookes ZL, Kaufman S. Long-term effects of repeated pregnancies (multiparity) on blood pressure regulation. Cardiovascular research 2004;64(1):179-86. doi: 10.1016/j. cardiores.2004.06.018. PubMed PMID: 15364626.

17. Bernstein L, Pike MC, Ross RK, Judd HL, Brown JB, Henderson BE. Estrogen and sex hormone-binding globulin levels in nulliparous and parous women. Journal of the National Cancer Institute 1985;74(4):741-5. PubMed PMID: 3857369.

18. Skilton MR, Serusclat A, Begg LM, Moulin P, Bonnet F. Parity and carotid atherosclerosis in men and women: insights into the roles of childbearing and child-rearing. Stroke. 2009;40(4):1152-7. doi: 10.1161/STROKEAHA 108.535807. PubMed PMID: 19211493.

19. Vaidya D, Bennett WL, Sibley CT, Polak JF, Herrington DM, Ouyang P. Association of parity with carotid diameter and distensibility: multi-ethnic study of atherosclerosis. Hypertension 2014;64(2):253-8. doi: 10.1161/HYPERTENSIONAHA.114.03285. PubMed PMID: 24842921; PubMed Central PMCID: PMC4184976.

20. Oner E, Erturk M, Birant A, Kalkan AK, Uzun F, Avci Y, et al. Fragmented QRS complexes are associated with left ventricular systolic and diastolic dysfunctions in patients with metabolic syndrome. Cardiology journal 2015;22(6):691-8. doi: 10.5603/CJ.a2015.0045. PubMed PMID: 26202657. 